\title{
ELEMEN NARATIF NOVEL 5 CM KARYA DONNY DHIRGANTORO DAN HORIZON HARAPAN PEMBACANYA
}

\section{NARRATIVE ELEMENTS 5CM NOVEL BY DONNY DHIRGANTORO AND HORIZON OF EXPECTATION THE READERS}

\author{
Muhammad fadli muslimin \\ Fakultas Sastra, Universitas Muslim Indonesia \\ fadlimuslimin@gmail.com
}

\begin{abstract}
ABSTRAK
Tujuan dari penulisan adalah untuk mendeskripsikan elemen naratif novel $5 \mathrm{~cm}$ karya Donny dhirgantoro dan horizon harapan pembacanya. Terdapat keterkaitan antara pengalaman pembaca dengan horizon harapannya, yakni pada luaran yang dihasilkan. Metode yang digunakan adalah analisis deskriptif kualitatif dengan memanfaatkan teori naratif populer dan horizon harapan Hans jauss. Hasil penelitian ini menunjukkan bahwa naratif populer yang terkandung dalam novel yang meliputi plot, tema, tokoh dan penokohan, latar, dan suasana menujukkan karya sebagai fiksi realis yang lebih menekankan pada realitas yang dialami pengarang; dari hal tersebut, horizon harapan Riza mantovani yang diwujudkan ke dalam film tidak terlepas dari pengetahuan tersebut yang berlandaskan pada budaya populer.
\end{abstract}

Kata kunci : pembaca, naratif, populer, horizon harapan

\section{ABSTRACT}

The purpose of the writing was to describe the narrative elements in the $5 \mathrm{~cm}$ novel and the horizon of expectation from Riza Mantovani as a reader. There was a link between the experience of the reader and his expectation horizon, that is, the resulting outcome. The method used was descriptive qualitative analysis by utilizing popular narrative theory and Hans Jauss's horizon of expectation. The results of this study indicated that the popular narrative contained in the novel which includes plot, theme, character and characterization, setting, and atmosphere denoted the work as a realist fiction that emphasized the reality experienced by the author; From this, the horizon of Riza Mantovani's expectation, which was manifested in films and it was inseparable from the knowledge-based on popular culture.

Keywords : reader, narrative, popular, horizon of expectation

\section{PENDAHULUAN}

Orientasi pasar masyarakat berdampingan dengan industrialisasi, urbanisasi, dan demokrasi menyebabkan peningkatan fenomena konsumsi terhadap mass literature. Fenomena mass literature berkaitan erat dengan budaya massa. dan Budaya popular merupakan oposisi dari high culture yang korelasinya berkaitan dengan efek negatif yang disebabkan oleh budaya massa yang mereduksi nilai yang melekat pada high culture. Dampak langsungnya, yaitu terletak pada eksplorasi yang dilakukan oleh penulis karya sastra yang mengikuti pasar budaya 
Tuah Talino

Tahun XIV Volume 14 Nomor 2 Edisi 4 Desember 2020

ISSN 0216-079X E-ISSN 2685-3043

Balai Bahasa Kalimantan Barat

popular. Meskipun demikian, unsur yang dapat mempertemukan masyarakat secara luas dapat ditemukan di budaya massa yang menjangkau seluruh pihak. Budaya massa/popular yang memiliki citra negative, yakni melawan kemapapan, menawarkan alternatif menjadi "pemersatu" masyarakat yang terpisahkan kelas dan satatus sosial (Fitryarini, 2012). Sastra popular atau fiksi populer, satu diantaranya, lahir dari keadaan tersebut.

Fiksi popular lazimnya banyak digemari kalangan remaja dan dewasa karena konten yang diusung mudah dicerna dan dekat dikalangan masyarakat, perkembangan fiksi sangat pesat seiring dukungan dari modernisasi, industri dan urbanisasi. Fiksi popular mendapat respon yang positif dari masyarakat terutama pada bidang sastra, sebagai salah satu pemenuh kebutuhan terhadap hiburan dan pengetahuan sastra bertransformasi mengikuti perkembangan sehingga banyak yang menyebutnya sebagi sastra popular. Sastra popular di Indonesia dapat dikategorikan pada jenis sastra yang muncul dan dianggap sebagai novel picisan yang berkembang sejak 1950-an (Adi, 2016:25)

Menyemat label sebagai sastra popular, satu diantara indikatornya yaitu mengacu pada tingkat penjualan dan minat masyarakat dalam mengkonsumsi bacaan tersebut. Semakin tinggi tingkat penjualannya, maka jenis sastra tersebut semakin laris dan seringkali mendapatkan label "best seller". Meskipun nilai estetika yang terkandung dalam sastra populer jauh berbeda dengan sastra adiluhung, tetapi sebagai salah satu jenis sastra, sastra populer tetap memiliki ruang tersendiri dikaji melalui teori-teori sastra yang ada saat ini.

Novel $5 \mathrm{~cm}$ adalah karangan dari Donny siregar, lahir di Jakarta, 27 Oktober 1978. Novel $5 \mathrm{~cm}$ adalah novel pertamanya yang pertama kali terbit tahun 2005 dan telah mendapatkan 23 kali cetak ulang yang menunjukkan betapa sukses cerita tersebut. Cerita ini bertolak pada kehidupan pribadi Donny bersama sahabat-sahabatnya ketika mendaki gunung. Karya ini termasuk ke dalam novel fiksi realis. Penerimaan oleh masyarakat khususnya anak muda menjadi satu di antara indikator kesuksesan novel ini. Penerimaan oleh masyarakat tidak dapat dipisahkan dari karyanya karena karya tersbut memilki sesuatu yang diharapkan oleh pembaca dan menyentuh keseharaian mereka. Dalam kurun waktu 7 tahun, transformasi dari novel terlihat pada tahun 2012, Rizal Mantovani mengangkat novel tersebut ke layar lebar dengan judul yang sama yaitu " $5 \mathrm{~cm}$ ". Film adaptasi novel tersebut mendapat sambutan yang begitu antusias dari masyarakat, sejak pertama kali diputar tanggal 12 November 2012, film "5 cm" telah meraup penonton sejumlah 5 juta. Ini adalah salah satu film adaptasi novel tersukses yang ada di Indonesia. Keberhasilan Rizal Mantovani dalam mengadaptasi Novel "5 $\mathrm{cm}$ " ke dalam film tidak terlepas dari pengalaman dan pengetahuan serta analisis terhadap kebutuhan masyarakat terhadap hiburan.

Kajian-kajian yang merespon terhadap novel dan film $5 \mathrm{~cm}$, pada dasarnya bukan merupakan hal baru. Ini dapat dilihat dari penelitian yang dilakukan oleh Andi Rahman yang berjudul Ekranisasi Novel 5 Cm Karya Donny Dirgantoro Terhadap Film $5 \mathrm{Cm}$ Karya Rizal Mantovani dan Implikasinya Pada Pembelajaran Sastra di SMA. Ia memfokuskan penelitiannya pada bentuk ekranisasi pada novel ke film $5 \mathrm{~cm}$. Ia berupaya untuk memperoleh implikasi ekranisasi dan mengkaitkannya dengan pembelajaran sastra di SMA (Rahman, 
2016). Di samping mencari pola ekranisasi pada $5 \mathrm{~cm}$ untuk pembelajaran sastra di SMA, oleh Kartini, Sarwit Sarwono, dan Bustanuddin lubis memberikan perspektif lain melalui pendekatan semiotiknya. Dalam penelitiannya yang berjudul Analisis Novel $5 \mathrm{~cm}$ karya Donny Dhirgantoro dengan Pendekatan Semiotik, ia berupaya untuk mengetahui angka dan makna. Upaya ini tentu memandang karya sastra dalam ikon, indeks, dan simbol (Kartini, Sarwono, \& Lubis, 2017). Pada konteks resepsi sastra, penelitian dari Yeni Yulianti berjudul Istirahatlah Kata-kata- Sebuah Kajian Resepsi Sastra, ia berupaya untuk menemukan pemanfaatan novel yang kemudian dijadikan titik tolak untuk mengantarkan anak bangsa ke konteks global melalui film (Yulianti, 2017). Menempatkan fokus kajian ini diantara kajian-kajian tersebut merupakan langkah untuk menemukan interpretasi yang berbeda dan memperkaya perspektif terhadap novel $5 \mathrm{~cm}$.

Untuk menempatkan posisi karya $5 \mathrm{~cm}$ dalam konteks horizon harapan pembaca, maka perlu dilakukan penelusuran secara naratif terhadap teks sehingga memungkinkan untuk melihat horizon harapan dari pembacanya. Terlepas dari elemen naratif, teks sebagai wacana tidak dapat dilepaskan dari pusaran fiksi sebagai wacana. Dalam hal ini pengarang berkonstribusi untuk menunjukkan eksistensi pengetahuannya melalui narasi yang dibangunnya dalam karya. Aprinus salam mengungkapkan hal serupa dalam jurnalnya Posisi fiksi popular di Indonesia. Ia menyatakan bahwa sebagai wacana, penulisan fiksi memiliki tujuan, kepentingan, bagi dirinya atau kelompoknya (Salam, 2002). Hal ini membuka suatu permasalahan yang jika ditinjau dari segi naratifnya dan dalam perspektif horizon harapan, yakni pada unsur naratif yang terkandung dalam novel dan adapatasi yang dilakukan rizal mantovani terhadap novel $5 \mathrm{~cm}$ ke dalam sebuah film. Berpijak pada rumusan masalah, maka tujuan dari penelitian ini, yaitu untuk mengungkapkan elemen naratif dan bagaimana horizon harapan Rizal Mantovani terhadap novel $5 \mathrm{~cm}$.

Dalam konstruksi naratif, novel dilahirkan oleh pengarang dengan mempertimbang struktur naratif. Mengaju pada istilah popular yang disematkan pada novel, unsur naratif dalam novel dikonstrasikan pada cerita, sehingga fokus yang dicapai yaitu elemen-elemen intrinsik yang terdapat dalam novel. Ida Rochani menguraikan dalam bukunya Fiksi Populer Teori Dan Metode Kajian bahwa fiksi popular memiliki struktur naratif yang dapat ditemukan di dalam novel. Istilah naratif atau yang lebih umum dikenal sebagai plot diketahui sebagai jalan cerita yang memuat sumber cerita, yakni adanya konflik. Konflik yang demikian melengkapi plot sehingga cerita menjadi menarik.(Adi, 2016)

Kedua, yaitu tema. Pada dasarnya tema dibagi ke dalam dua, yaitu tema utama dan tema sampingan. Tema tidak lain adalah inti pembicaraan yang ingin disampaikan oleh pengarang. Tema dalam fiksi popluer lebih sederhan dan cenderung didramatisasikan sebagai bahan pokok suatu cerita (Adi, 2016:44). Ketiga, yaitu penokohan. Tokoh adalah hal yang wajib ada di dalam novel, baik novel popular ataupun adiluhung. Tanpa adanya tokoh, alur cerita otomatis tidak dapat berjalan. Penokohan dalam novel populer figambarkan adakalanya terdiri dari beberapa tokoh utama, sedangkan tokoh-tokoh lainnya hadir untuk menjelaskan penggambaran tokoh utama. Tokoh di dalam novel dibedakan ke 
dalam dua poros, yaitu tokoh statis dan tokoh dinamis. Tokoh statis yaitu tokoh yang wataknya tidak berubah dari awal cerita hingga akhir cerita, sedangkan tokoh dinamis adalah tokoh yang berubah.

Keempat, yaitu, latar. Latar berperan penting untuk menunjuak tema tokoh, tema, dan penokohan dalam novel. Tempat dan waktu kejadian cerita merupakan unsur yang menunjukkan jenis cerita dan konteks cerita. Terkahir, yaitu suasana. Setiap karya fiksi popular ditulis dengan maksud tertentu yang tidak hanya tercermin dalam tema, tetapi juga dalam suasana cerita. Setiap karya memiliki suasana pokok tertentu untuk memberikan warna kepada cerita (Adi, 2016)

\section{Resepsi dan horizon harapan}

Istilah Resepsi berasal dari kata recipere (Latin), atau reception (Inggris) yang berarti penerimaan. Resepsi sastra adalah penerimaan karya sastra oleh para pembaca atau penikmat. Dalam arti luas resepsi sastra diartikan sebagai pengolahan teks sastra, cara-cara pemberian makna oleh pembaca terhadap karya sastra sehingga dapat memberikan respons terhadapnya (Sehandi, 2014:157). Jauss berpendapat bahwa karya sastra ada hanya jika ia telah diciptakan kembali atau 'dikonkretkan' dalam otak pembaca (Newton, 1990:158)

Teori Resepsi ( Rezeptionasthetik), yang muncul di Jerman antara tahun 1960-1980 berfokus pada interaksi antara teks dan pembacanya daripada penulisnya. Teori respesi berfokus pada pengaruh sosial secara keseluruhan dari sebuah karya sastra dalam rentan waktu tertentu, menyampaikan nilai-nilai moral dan pemahaman lingkungan budaya dan sosial.(Srouji-Shajrawi, 2013:2).

Jauss menyatakan bahwa sastra memiliki dimensi yang tidak dapat dipisahkan dari karakter estetis dan fungsi sosialnya. (Jauss,1985 : 18). Hal in berarti bahwa hubungan antara karya sastra itu sendiri tidak bisa dilepaskan dari fungsi sosial yang ada di masyarakat, yang tentunya melibatkan Pembaca sebagai bagian yang menjalankan fungsi sastra. Karya itu juga tidak dapat dibatasi pada periode waktu karya itu dihasilkan karena ia terus mempengaruhi generasigenerasi pembaca berikutnya, tidak pula ia semata-mata dapat disesuaikan dengan pembaca modern sebagai menitis waktunya sendiri. (Newton, 1990:158)

Untuk memahami hubungan yang terjadi antara pembaca dalam memaknai teks karya sastra dapat dipahami melalui 7 tesis Jauss dalam esainya Literary History as a Challenge to literary Theory yang terdapat dalam buku Towards an Aesthetics of Reception (1982). Tujuh tesis tersebut oleh jauss menghubungkan antara teks dan pembacanya yang memiiki 2 aspek penting yaitu : sejarah dan estetiknya (Jauss, 1985 : 20) Pertama, ketika pembaca membaca teks untuk pertama kalinya kemudian membandingkan dengan nilai estetikanya dengan teks lain. Kedua, pembaca akan memberi pemahamannya terhadap teks dari generasi ke generasi.

Fokus perhatian jauss adalah penerimaan sebuah teks. Minat utamanya bukan pada tanggapan seorang pembaca tertentu pada suatu waktu tertenu, melainkan pada perubahan-perubahan tanggapan, interpretasi, dan evaluasi pembaca umum terhadap teks sastra yang sama atau teks-teks yang berbeda dalam kurun waktu berbeda.(Sehandi, 2014:159) 
Tuah Talino

Tahun XIV Volume 14 Nomor 2 Edisi 4 Desember 2020

ISSN 0216-079X E-ISSN 2685-3043

Balai Bahasa Kalimantan Barat

Jauss beranggapan karya sastra lama merupakan produk masa lampau yang memiliki relevansi dengan masa sekarang relevansi dengan masa sekrang, dalam arti ada nilai-nilai tertentu untuk para pembacanya. Untuk menggambarkan relevansi tersebut, Jauss memperkenalkan konsep "Horizon Harapan" (Horizon of expectation) yang memungkinkan terjadinya penerimaan dan pengolahan dalam batin pembaca terhadap sebuah objek literer. Semua pembaca membaca karyakarya sastra dengan pengharapan tertentu setelah membandingkan dengan membaca karya-karya lain terutama karya-karya dengan gaya yang sama.

Melalui penelitian resepsi, Jauss ingin merombak sejarah sastra masa itu yang terkesan hanya memaparkan sederet pengarang dan jenis sastra. Focus perhatiannya adalah proses sebuah karya sastra diterima, sejak pertama kali ditulis sampai penerimaan selanjutnya oleh pembaca. .(Sehandi, 2014:159) Jauss melihat hubungan antara karya sastra dan pengaruh historisnya.

Menelaah lebih jauh untuk mengungkapkan rumusan masalah yang telah dipaparkan sebelumnya, selanjutnya dari ketujuh tesis yang diungkap oleh Jauss kemudian digunakan tesis kedua yang berfokus kepada horizon harapan. Menurut Jauss, tesis kedua berfokus pada posisi karya sastra dalam mempengaruhi pembacanya. Pembaca yang memiliki sebuah kesadaran individu yang bersifat momenter dan personal, dan kesadaran inilah yang digunakan oleh pembaca untuk membangun memori pembaca terhadap karya yang dibacanya. Dalam konteks ini horizon harapan pembaca berperan dalam mempertahankan isi cerita atau mengubahnya atau mengorientasikan dengan selera zamannya. (Jauss, 1982:2223)

Horizon harapan seseorang ditentukan oleh tiga macam yaitu, (1) normanorma umum atau nilai putisnya, (2) hubungan yang lengkap diantara karya-karya yang secara historis ada disekitarnya, (3) pertentangan antara fiksi dan fungsi utama bahasa (Jauss, 1983:24) Sebagai contoh adalah kemampuan pembaca untuk memahami sebuah teks melalui horizon harapan yang sempit maupun luas berdasar pada wawasan yang dimiliki oleh pembacanya.

\section{METODE}

Metode adalah cara yang telah teratur dan terpikir baik-baik untuk mencapai suatu maksud yang ditentukan (Indonesia, 2008:954). Lebih lanjut, metode menyangkut masalah cara kerja; yaitu cara kerja untuk memahami objek yang menjadi sasaran ilmu yang bersangkutan (Sangidu, 2004: 13). Jadi, metode adalah cara kerja untuk memahami suatu objek tertentu. Penelitian ini menggunakan metide analisis deskriptif kualitatif. Pada penelitian ini, data diperoleh dari dua sumber, yaitu sumber data primer dan data sekunder. Data primer, yaitu novel 5 cm karangan Donny Siregar dan data sekunder dari narasi yang dibagun dalam film $5 \mathrm{~cm}$ karya rizal mantovani. Selain itu, data lainnya, yaitu referensi yang relevan dari buku dan jurnal. Analisis data dilakukan dengan cara menginterpretasi dilakukan menginterpretasi novel $5 \mathrm{~cm}$ berdasarkan unsur intrinsiknya. Setelah itu, mengungkapkan bagaimana pembaca, dalam hal ini Rizal Mantovani, melakukan pembacaan terhadap novel yang selanjutnya ia adaptasi menjadi sebuah film berdasarkan horizon harapannya yang tidak terlepas dari pemaknaan tekstual terhadap novel. 


\section{PEMBAHASAN}

\section{Elemen naratif novel $5 \mathrm{~cm}$}

Objek fiksi diciptakan oleh penulis yang selanjutnya dihadirkan sebagai objek sosial di dalam novel. Objek fiksi tersebut tidak saja hadir sebagai ceritacerita yang dikarang oleh penulis tetapi merupakan eksistensi yang tidak disengaja pada sebagaian pembacaan masyarakat. Objek fiksi tersebut hadir sebagai hasil buah pikiran imajinatif penulisnya dan tetap hadir sebagai konsekuensi atas proses kreatif yang disengaja, dan objek fiksi yang disusun menggunakan nama-nama fiksi (Frederick, 2013:90). Penyusunan objek fiksi menggunakan nama-nama fiksi tentu bukanlah upaya untuk mengaburkan realitas tetapi memberikan unsur imajinatif terhadap tokoh agar pembaca dapat menafsirkannya. Sebagai fiksi, struktur naratif novel merupakan unsur internal yang membangun cerita oleh penulis.

Plot merupakan unsur naratif yang membangun cerita dari awal hingga akhir. Dalam novel $5 \mathrm{~cm}$ karya, plot memuat konflik yang bersumber dari tokohtokoh. Serangkaian peristiwa terjadi diantara ke-lima sahabat tersebut. Serangkaian persitiwa tersebut membentuk keseluruhan cerita di dalam novel. Peristiwa-peristiwa yang dialami oleh ke-lima sahabat ini mengantarkan mereka ke suatu klimaks sebuah persahabatan, yaitu kebosanan dan kejenuhan.

Plot atau alur cerita di dalam novel dibangun berdasarkan kejenuhan terhadap persahabatan yang selama ini mereka jalani. Persahabatan yang mononton dan itu-itu saja. Kejenuhan dirasakan oleh ke-5 tokoh utama tersebut.

"Mungkin kita emang harus ngeliat dunia lain di luar tongkrongan kita dulu, jangan berlima melulu ke mana- mana," kalimat Zafran tentang Plato barusan menyentakkan ke-apaadaan-nya diri Arial. (Siregar, 2012:65)

Persahabatan yang dihadapi oleh Zafran, Arial, Genta, Ian, Riani merupakan poteret kejenuhan yang dialami oleh mereka berlima. Inilah konflik yang tercipta diantara 5 sahabat. Mereka bersepakat dan yakin bahwa kejenuhan dalam persahabatan yang mereka alama disebababkan oleh kebersamaan yang sistemtasi dan monoton sehingga menutup kemungkinan mereka untuk dapat menjalin hidup lain di luar sana. Keperihatinan ini memicu mereka untuk bereaksi terhadap kondisi tersebut. Zafran mengusulkan sebuah ide sekaligus dapat dikatakan sebagai konflik lainnya

"Kita keluar sebentar aja, bermimpi lagi masing-masing tentang kita, nanti pas ketemu lagi, pasti lain lagi, lain ceritanya, lain lagi orangnya, mungkin nanti Ian jadi kurus (Siregar, 2012:68)

Usulan menjalani hidup masing-masing diutarakan Zafran merupakan titik balik sebuah perjalanan baru yang disetujui bersama oleh mereka. Sebuah perjalanan baru yang akan dijalani selama 3 bulan. Aktivitas-aktivitas yang belum pernah dilakukan, mereka mencoba menemukan sebuah aktivitas lain yang sebelumnya sempat mereka tinggalkan hingga tiba waktu mereka untuk kembali berkumpul. Momen tersebut dimanfaatkan

\section{Tema Novel $5 \mathrm{~cm}$}

Tema yang merupakan inti pembicaraan disampaikan oleh penulis secara realis. Realisme merupakan sebuah konsep tentang kehidupan sehari-sehari. 
Tuah Talino

Tahun XIV Volume 14 Nomor 2 Edisi 4 Desember 2020

ISSN 0216-079X E-ISSN 2685-3043

Balai Bahasa Kalimantan Barat

Penggamabaran objek sebagaimana realitas sesungguhnya di masyarakat. Tanpa adanya penambahan berlebihan terhadap objeknya. Dengan kata lain, realisme adalah sesuatu yang nyata. Hal ini dinyatakan oleh Miller (2002) tentang aspek realisme yang secara umum dibagi dua yaitu ilustrasi yang memandang realisme sebagai objek nyata dan independent (Brock \& Mares, 2010) pada pengertian ini, objek fisik di dalam novel secara indrawi nyata di kehidupan sehari-hari. Kesadaran terhadap objek yang ditampilkan dapat ditemukan di kehidupan seharihari dan bukanlah sesuatu yang diciptakan tanpa merujuk kepada suatu realitas yang ada.

Pengarang menyematkan tema pada novel ini melalui dimensi persahabatan. Tema ini merupakan tema umum yang dapat ditemukan pada kehidupan seharihari. Persahabatan yang ditampilkan adalah persahabatan yang terjalin diantara lima orang anak muda di Jakarta. Kesederhanaan tema dalam fiksi popular merupakan ciri yang dapat ditemukan dalam novel ini. Misalnya, ketika firman merenungkan tentang sahabat-sahabatnya yang dia kenal semenjak kuliah atau tentang perdebatan zafran dengna Ian tentang Bola. Topik-topik yang diperbincangkanpun cenderung dalam tataran wajar dan tidak ada unsur dramtisasi yang dihadirkan.

"The Leader". Enggak ada yang tahu kalo Genta adalah fans

berat Riani, bahkan Riani sendiri enggak ngerasa. (12)

Misalnya saja Genta pada kutipan diatas yang merupakan teman sekaligus fans berat Riani. Dia memilki kemiripan hobi dengan riani yang menyukai berbagai jenis film. Riani adalah sosok perempuan cerdas yang yang ditampilkan dalam Batasan wajar sebagaiman sosok perempuan cerdas pada umumnya. Dia memiliki charisma layaknya perempuan cerdas, cerewet, dominan, dan penampilan yang santai, serta turut serta sebagai aktivis di kampu. Hal ini menandakan bahwa tema persahabatan disini merupakan tema yang hidup pada keseharian persahabatan pada umumnya di masyarakat.

\section{Tokoh dan penokohan}

Tokoh dan penokohoan dalam novel $5 \mathrm{~cm}$ terdiri dari beberapa tokoh yang secara eksplisit digambarkan oleh narrator. Tokoh pertama yaitu Ariel, seorang mahasiswa fakultas hukum. Ariel digambarkan sebagai orang yang paling ganteng, atletis, sabar melalui pemaparan narrator yakni Zafran

“...Ariel adalah sosok yang paling ganteng diantar mereka. Arial yang satu ini adalah Arial control B alias Arial Bold dan Arial black karena badanya gede dan kulitnya item, ke mana-mana selalu pakai sepatu basket..." (Siregar, 2012:6)

Penggambaran sosok Ariel pada novel merupakan langkah penulis untuk menciptakan karakter yang Tangguh diantara yang lainnya. Sosok Arial yang mudah bergaul dan pemecah suasana menjadi ciri khasnya. Disisi lain, ia ditampilkan sebagai sosok yang cenderung antipati terhadap pelajaran. Ini dibuktikan dengan ketidaktertarikannya pada hukum itu sendiri yang sedangkan ia menjalani kehidupan sebagai mahasiswa hukum.

Tokoh selanjutnya yaitu, Riani. Ia adalah sosok cantik, cerdas, dominan, cerewet yang sangat sibuk dengan karir organizernya. Sikapnya yang dominan 
diantara sahabat-sahabatnya merupakan ciri khasnya. Baik potensi akademik maupun non-akademik, ditunjukkan Riani di atas rata-rata mahasiswa pada umumnya.

“...Riani pakai kacamata, cantik, cerdas, dan seorang N-ACH sejati. Mukanya gabungan antara Lisa Loeb sama Kate Winslet (nah loh?) Bodinya ? persis Kate Winslet." Hal. 8

Rutinitas yang dilakukan oleh Riani bukanlah suatu penggambaran yang berlebihan. Sosok ini dianggap sebagai penyeimbang di tengah-tengah ragam karakter yang coba dibangun oleh penulis. Meskipun tampaknya Riani adalah sosok yang ideal, namun ternyata ia bukanlah sosok tanpa celah. Kehidupan pribadinya masih ditampilkan minus. Sosok cerdas dan pintar itulah yang menjadikan ia mempunyai standar tinggi terhadap lelaki.

Zafran sosok penyair dan lugas dalam berbicara, mengatakan sesuatu yang seharunya di katakan. Tokoh ini merupakan representasi lelaki romantis dengan berbagai koleksi bacaan yang telah dilumatnya, namun cenderung dianggap aneh oleh teman-temannya.

“... Seorang penyair yang selalu bimbang...”(Siregar, 2012:9)

“...Zafran adalah orang yang akan bilang apa apa aja yang dia mau bilang, agak saklek tapi kocak karena kalui dia udah ketemu sama Riani, kayaknya bisa bikin orang bingung apa yang mereka obrolin..." (Siregar, 2012:11)

Sebenarnya Zafran, dibalik itu semua, adalah sosok yang paling peduli terhadap teman-temannya. Ia yang pertama kali menyadai bahwa persahabatan mereka sedang tidak baik-baik saja. Ia juga yang mengusulkan bahwa harus ada suatu perubahan dalam persahabatan mereka. Dan ia juga yang membimbing teman-temannya untuk saling menemukan diri masing-masing dalam dunia yang baru.

Sosok lainnya yang memberikan nuansa hidup pada persahabatan mereka adalah Ian. Ian bertubuh gempal, gemar makan Indomie, suka bermain PS2 dan menyukai VCD bokep.

"...yang ini badannya bengkak....Ian adalah orang yang tidak peduli sama siapa aja kecuali bola..."(Siregar, 2012:17)

Gambaran ini setidaknya menggambarkan sosok Ian yang cukup nyentrik dibadingkan teman-teman lainnya. Ia merupakan tokoh yang fanatik terhadap satu hal yaitu bola. Disamping itu, ia adalah seorang pekerja keras. Ia membuka usaha sendiri. Karakater yang ditampilkan Ian membuat ia disenangi oleh semua temannya karena pada dasarnya Ian bukanlah sosok yang penentang meskipun terkadang berdebat dengan zafran.

Genta dalam persahabatan mereka disebut sebagai pemimpin mereka karena mampu mengayomi dan mewadahi semua keluh kesah teman-temannya. Genta dianggap sebagai penerjemah dari segala permasalahann yang ada diantara temantemannya. Genta dapat dikatakan sebagai tokoh yang mampu untuk masuk dan mengimbangi yang lainnya.

“...Genta bisa dibilang adalah orang yang mementingkan orang lain daripada dirinya sendiri..." hal. 12

“...anehnya keempat temannya paling nurut sama Genta..." 
Tuah Talino

Tahun XIV Volume 14 Nomor 2 Edisi 4 Desember 2020

ISSN 0216-079X E-ISSN 2685-3043

Balai Bahasa Kalimantan Barat

Karakter Genta merupakan karakter lengkap yang dapat memayungi semua teman-temannya. Dari kutipan di atas dapat diketahui bahwa ia merupakan tokoh yang arif dan bijaksana sehingga ia dapat diterima semua temannya serta tempat berbagai cerita dan perasaan. Ia dianggap pusat oleh teman-temannya.

\section{Latar}

Tema, tokoh dan penokohan dari novel $5 \mathrm{~cm}$ dihadirkan pada suatu masa di Kota Jakarta yang penuh dengan hiruk-pikunya kondisi ibu kota. Mereka disibukkan oleh aktivitas-aktivitas rutin warga kota yang membahagiakan dalam kondisi tertentu tetapi menjenuhkan pada bagian yang lain.

“...mereka memang bahagia, tetapi diri mereka kosong dan mereka nggak pernah menemukan siapa diri mereka sebenarnya... mereka nggak punya mimpi..."(hal.62)

Disamping faktor kondisi kota Jakarta yang dipenuhi oleh kejenuhan, persoalan pertemanan mereka pun menambah internal diantara mereka. Kebuthan terhadap sebuah latar lain yang dapat mencairkan suasana rutinitas dan persahabatan mereka terjawab dengan ide dan gagasan Zafran tentang suatu perjalanan mendaki puncak gunung Mahameru.

Latar alam dijadikan tempat pemutus kejenuhan yang melanda mereka di Ibukota. Latar tempat yang memberikan mereka Susana alam sekaligus tantangan bagi diri mereka dan pershabatanan mereka.

“...Pukul setengah tiga lebih mereka tiba di stasiun Malang..." hal. 193

“...Angkot carteran perlahan meninggalkan Stasiun kereta...” hal. 194

“..Mas Gembul meperlambat angkotnya dan berhenti di sebuah terminal kecil yang dipenuhi Jip-jip besar... "hal. 204

“...Keenam sahabat itu juga berdiri berdesakan, diantara para pendaki lain..." hal.207

Malang dipilih oleh mereka sebagai tempat untuk menguraikan kejenuhan dan mencari sebuah kebebasan diri. Malang merupakan kota wisata yang terkenal dengan puncak tertingginya di pulau Jawa yaitu gunung Mahameru. Mereka berlima bukanlah seorang pendaki tetapi Gunung Mahameru merupakan tempat yang menjadi tantangan sekaligus ajang mempererat persahabatan mereka.

Latar ini merupakan tempat yang populis dan akrab bagi pembaca. Bukanlah sebuah hal yang sulit untuk mengidentifikasi wilayah ini disebabkan Gudang pengetahuan pembaca akrab dan erat dengan wilyah tersebut. Tentu pertimbangan inilah menjadi jangkauan popular yang dialamatkan bagi pembaca untuk dapat menikmati Novel $5 \mathrm{~cm}$ sebagai karya popular. Meskipun terdapat indikator lain misalnya pada tema yang diangkat yaitu persahabatan.

\section{Adaptasi film terhadap Novel $5 \mathrm{~cm}$}

Novel $5 \mathrm{~cm}$ karangan Donny Siregar adalah objek material pada analisis resepsi Jauss, objek material adalah objek yang menjadi lapangan penelitan (Faruk, 2015:23) objek material ini dipergunakan sebagai dasar analisis untuk mengetahui bentuk penyambutan apa yang telah dilakukan oleh Rizal mantovani setelah melalui pembacaan yang dilakukan serta mengunggakapkan horizon harapannya dengan menggunakan teori resepsi Jauss. 
Tuah Talino

Tahun XIV Volume 14 Nomor 2 Edisi 4 Desember 2020

ISSN 0216-079X E-ISSN 2685-3043

Balai Bahasa Kalimantan Barat

Rizal Mantovani berprofesi sebagai sutradara film, ia melahirkan karya baru dalam bentuk film setelah pembacaan yang dilakukannya terhadap Novel $5 \mathrm{~cm}$, dalam pembacaan tersebut Rizal melandasi penciptaan karya baru berdasarkan budaya pop. Segmentasi pasar yang dituju adalah hiburan untuk masyarakat, maka tak heran jika film ini sama larisnya dengan Novel $5 \mathrm{~cm}$ itu sendiri.

Rizal Mantovani lahir di Jakarata, 12 Agustus 1967, selain sebagai sutradara film , dia juga dikenal sebagai sutradara video klip. Film pertama yang dibuat olehnya adalah Kuldesak (1998) dan berturut-turut disusul oleh beberapa film sejumlah 24 film, dan yang terbaru adalah bulan terbelah di langit Amerika 2 (2016). Film lainnya, pada masanya, film $5 \mathrm{~cm}$, yang merupakan film film adaptasi novel, menyita perhatian dan sukses. Film ini mendapatkan lebih dari 2 juta penonton selama pemutaran perdananya. Novel dengan judul yang sama, yaitu $5 \mathrm{~cm}$, lebih dahulu telah jadi konsumsi masyarakat dan mendapat perhatian di masyarakat hingga mendapatkan 23 kali cetak ulang.

Secara umum, film ini mengangkat peristiwa-peristiwa yng nyaris serupa dengan Novel aslinya, film ini berkisah tentang 5 orang sahabat yaitu Genta diperankan oleh Fredi Nuril, Arial (Denny Sumargo, Zafran (Herjunot Ali), Riani (Raline Shah), Ian (Igor Saykoji) yang melakukan pendakian gunung Mahamaru setelah sebelumnya memutuskan untuk berpisah selama 3 bulan untuk mengejar masing-masing mimpi mereka, selama 3 bulan tersebut mereka tidak menjalin komunikasi apapun satu dengan yang lainnya sampai Zafran mengabari mereka melalui handphone untuk sebuah pertemuan dan membawa bekal pendakian dan bertemu di Stasiun Pasar Senen dan melakukan perjalan menggunakan kereta ke Malang yang selanjutnya menuju Gunung Mahameru, puncak tertinggi Jawa.

Selama perjalan ke Puncak Mahameru banyak terjadi peristiwa penting yang semakin merekatkan hubungan persahabatan mereka. Pendakian ke Puncak Mahameru menguras tenaga dan pikiran mereka, tetap tetap komitmen untuk sampai ke atsa dengan selalu memenag janji $5 \mathrm{~cm}$, taruh mimpi atau cita-cita mu, di depan kening kamu. Jangan menempel biarkan dia menggantung mengambang $5 \mathrm{~cm}$ di depan keningmu.

Kisah percintaan Genta, yang pada akhirnya berani mengakui cintanya kepada Riani, tetapi ternyata selama ini Riani mencintai diam-diam orang lain, yaitu Zafran. 10 tahun berlalu setelah pendakian Mahameru, mereka kembali bertemu di rumah Ariel. Ariel telah menikah dengan Indi dan mempunyai seorang anak, Zafran menikah dengan Riani dan juga memiliki anak, Ian berhasil menikah dengan Happy Salma, dan Genta masih tetap sendiri hingga dia kembali bertemu dengan Dinda dan mengajaknya berbicara dan dia terpesona dengan Dinda yang telah semakin dewasa dan melanjutkan ke jenjang Magister.

Apa yang dilakukan oleh Rizal Mantovani adalah kongkretisasi. Kongkretisasi adalah hal yang tidak dapat dilepaskan dari horizon harapan pembacanya, kongkretisasi sebagai langkah untuk mengisi ruang-ruang yang dianggap oleh pembaca masih kosong terhadap karya yang dibacanya, butuh sebuah langkah untuk mengisi ruang tersebut sesuai dengan horizon harapan pembacanya, Ingarden menyatakan bahwa kongkretisasi dilukiskan sebagai sikap estetik, rekonstruksi sebagai pengobjektifan suatu tema. Kongkretisasi akan 
Tuah Talino

Tahun XIV Volume 14 Nomor 2 Edisi 4 Desember 2020

ISSN 0216-079X E-ISSN 2685-3043

Balai Bahasa Kalimantan Barat

mengatur secara fungsional dengan berkesan pengenalan karya sastra dan mesti dibuktikan sebelum suatu rekonstruksi

\section{Horizon harapan Rizal Mantovani}

Jauss mengungkapan keduanya. The analysis of the literary experience of the reader avoids the threatening pitfalls of psychology if it describes the reception and the influence of a work within the objectifiable system of expectations that arises for each work in the historical moment of its appearance of already familiar works, and form the opposition between poetic and practical language (1983:22). Analisis pengalaman sastra pembaca menghindari ancaman perangkap psikologi jika tidak menggambarkan sebuah resepsi dan pengaruh karya terhadap sistem harpan yang dapat secara objektif muncul dari setiap karya pada momen sejarahnya dari kehadirannya dari karya-karya yang familiar, dan dari oposisi antara bahasa puisi dan bahasa praktis.

Horizon Harapan adalah kerangka pemahaman pembaca terhadap suatu karya atas dasar pembacaan terdahulu (Ratna, 2013:207). Pembaca karya memiliki pengharapan tertentu terhadap suatu karya yang telah dibacanya setelah melakukan pembandingan dengan karya-karya serupa yang lain. Jadi tidak menutup kemungkinan bahwa dalam melakukan pembacaan seseorang dipengaruhi oleh bacaan lain yang dapat mengubah interpretasi makna terhadap karya yang telah dibacanya.

Rizal Mantovani tetap mengangkat tema serupa dengan novelnya yaitu persahabatan antara lima orang anak muda, secara keseluruhan Rizal mengikuti alur cerita pada novel $5 \mathrm{~cm}$, Rizal tetap mempertahankan nama-nama tokoh utama yaitu Genta, Zafran, Ian, Ariel, Riani tetapi beberapa tokoh pembantu pada novel tidak dimunculkan pada novel, antara lain Mas Suhartono, seorang supir angkot yang mengantarkan mereka ke terminal kecil hingga selanjutnya mengantar ke Mahameru

“...oh namanya Mas Suhartono, kenalan dulu dong, mas... ”hal. 197

Dan ada sosok mahasiswa berjaket almamater yang tidak dimunculkan ketika mahasiswa tersebut berpapasan dengan Zafran dan Ian, jika disimak pada novel $5 \mathrm{~cm}$

“...duluan ya mas-mas dan mbak-mbak.a yo sebentar lagi sampai puncak langsung upacara bendera di atas. Seorang mahasiswa yang memakai jaket almamater lewat sendirian, membawa bendera merah putih..."

Karakater lain yang tidak dimunculkan adalah Daniek sosok yang ditemua mereka sewaktu masih di mobil jip dalam pemberangkatan menuju desa Ranu Pane, Ian memiliki hobi yang sama dengan Daniel sehingga selama perjalanan mereka berbagi infromasi mengenai kamera. Daniel juga yang di akhir cerita menikah dengan Dinda.

Terjadi penyempitan karakter yang dilakukan oleh Rizal Mantovani kepada tokoh Zafran. Zafran tidak lagi berpuitis menggunakan kutipan-kutipan bahasa inggris beserta menyanyi lagu-lagu bahasa inggris sehingga mempengarhui tokohtokoh lain yang biasanya merespon setiap ujaran dari Zafran yang puitis tersebut semuanya menggunakan lagu bahasa Indonesia, ataupun puisi dan syair Indonesia. 
Unsur yang mengandung rokok pada novel dihilangkan oleh Rizal mantovani, dalam setiap adegan di film $5 \mathrm{~cm}$ tidak dapat ditemukan baik Genta maupun Zafran yang merokok. Semuanya digambarkan tanpa rokok. Dan juga penghilangan bahasa-bahasa tak sopan mengenai kebiasan Ian yang menonton film "biru"

Rizal Mantovani mengubah akhir cerita dari novel yang ditulis oleh Donny Dhirgantoro, jika pada Novel setelah sepuluh tahun setelah pendakian bersama yang mereka lakukan di Gunung Mahameru masing-masing telah memililki keluarga masing-masing, Zafran berpasangan dengan Riani dan memiliki anak, Ariel berpasangan dengan Indy dan memilki anak, Ian berpasangan dengan Happy Salma dan memiliki anak, Dinda berpasangan dengan Daniel, dan Genta berpasangan dengan citra. Pada film $5 \mathrm{~cm}$ Rizal Mantovani menempatakn zafran berpasangan dengan Riani, Ariel dengan Indy, Ian dan Happy Salma, tetapi berbeda dengan status dari Genta dan juga Dinda. Genta pada saat diadakan reunian di Rumah Ariel datang sendirian dan tidak memiliki pasangan siapapun, ketika Genta masuk ke dalam rumah Ariel dia bertemu dengan Dinda turun dari tangga dan menghampirinya, dan bercerita mengenai magister S2-nya serta mendiskusikan mengenai tugas ekonomi dan disana Genta terpesona melihat Dinda.

\section{PENUTUP}

Novel $5 \mathrm{~cm}$ karya Donny Dirgantoro Sireger merupakan novel fiksi realis yang mana ceritanya adalah persentuhan langsung Donny sebagai penulis. Novel ini memuat elemen naratif, yaitu Plot yang dibangun berdasarkan kejenuhan terhadap persahabatan yang selama ini mereka jalani; tema, berupa persahabatan pada kehidupan sehari-hari; tokoh dan penokohan, terdiri dari tokoh utama Ariel yang penyabar, Riani yang cerdas dan cerewet; Zafran yang lugas dan tegas; Ian yang nyentrik; dan Genta yang merupakan tokoh yang arif dan bijaksana

Dan horizon harapan dari Rizal Mantovani yakni ia menggambarkan tokohtokoh fiksi di dalam novel sebagai unsur pembangun fiksi realisnya dengan memberikan citra sesuai dengan objek sosial yang ada. Ia tidak memberikan unsur-unsur berlebihan di dalam dunia fiksi realisnya. Hal ini menegaskan bahwa pengarang hendak menyampaikan gambaran fantasinya kepada pembacanya. Pembaca dalam hal ini memiliki horizon harapan tersendiri berhak mencairkan ataupun mengaktualisasi ulang terhadap pembacaannya, sehingga melahirkan adaptasi lain menanggapi hasil pembacaan tersebut.

Rizal Mantovani menjadikan pengalaman dan pengetahuan bersastra yang dimiliki berdasarkan pembacaannya dari berbagai teks-teks lain sekaligus mempertententangkan antara fiksi dan kenyataan sebagaimana diungkapkan oleh Jauss merefleksikan horizon harapan yang dimilikinya dalam mengkongkritkan ruang-ruang kosong yang terdapat pada karya yang dibacanya yaitu Novel $5 \mathrm{~cm}$, selanjutnya melalui horizon harapan yang dimiliki, dia memproduksi sebuah karya lain sebagai bentuk lain sebuah hasil pembacaan. Ruang-ruang kosong yang dianggap penting oleh Rizal Mantovani dapat berupa penambahan ataupun pengurang pada tokoh, peristiwa, hasil akhir dari cerita, berlandaskan pada budaya 
Tuah Talino

Tahun XIV Volume 14 Nomor 2 Edisi 4 Desember 2020

ISSN 0216-079X E-ISSN 2685-3043

Balai Bahasa Kalimantan Barat

pop yang menginginkan sebuah hiburan untuk masyarakat yang bersifat edukatif sehingga lahirlah perwujudan baru yaitu film $5 \mathrm{~cm}$.

\section{DAFTAR PUSTAKA}

Adi, I. R. (2016). Fiksi Populer: Teori \& Metode Kajian. Yogyakarta: Pustaka Pelajar.

Brock, S., \& Mares, E. (2010). Realism and Anti-realism. Durham: MPG Books Group.

Fitryarini, I. (2012). Pembentukan Budaya Populer dalam Kemasan Media Komunikasi Massa. Jurnal Komunikasi Makna, 2(2), 1-14.

Frederick, K. (2013). The Social Character of Fictional Entities. In C. Barbero, M. Ferraris, \& A. Voltolini (Eds.), From Fictionalism to Realism (pp. 87-110). United Kingdom: Cambridge Scholars Publishing.

Indonesia, K. B. (2008). Kamus Bahasa Indonesia. (Sugiyono \& Y. Maryani, Eds.). Jakarta: Pusat Bahasa Departemen Pendidikan Nasional.

Kartini, Sarwono, S., \& Lubis, B. (2017). Analisis Novel $5 \mathrm{~cm}$ karya Donny Dhirgantoro dengan Pendekatan Semiotik. Jurnal Korpus, 1(1), 73-82.

Newton, K. M. (1990). Interpreting the Text: A Critical Introduction to the Theory and Practice of Literary Interpretation. United Kingdom: Palgrave Macmillan.

Rahman, A. (2016). Ekranisasi Novel 5 Cm Karya Donny Dirgantoro Terhadap Film 5 Cm Karya Rizal Mantovani dan Implikasinya Pada Pembelajaran Sastra di SMA. Universitas Mataram.

Ratna, N. K. (2013). Teori, Metode, Dan Teknik Penelitian Sastra. Yogyakarta: Pustaka Pelajar.

Salam, A. (2002). Posisi Fiksi Populer di Indonesia. Humaniora, 14(2), 201-210.

Sehandi, Y. (2014). Mengenal 25 Teori Sastra. Yogyakarta: Ombak.

Siregar, D. (2012). $5 \mathrm{~cm}$. Jakarta: Grasindo.

Srouji-Shajrawi, C. (2013). A Model for Applying Jauss' Reception Theory: The Role of Rumors in the Reception of "Memory in the Flesh." Madarat (Orbits) - Studies in Thought, Culture and Literature, 6, 1-23.

Yulianti, Y. (2017). Istirahatlah Kata-Kata: Sebuah Kajian Resepsi Sastra. Tuah Talino, 11, 108-117. 